\title{
Iron status in a general practice and its relationship to morbidity
}

\author{
BY M. J. LEYLAND, H. HARRIS AND P. J. BROWN \\ Department of Haematology, University of Liverpool, Crown Street, PO Box 147, \\ Liverpool $L 693^{B X}$
}

(Received 7 March 1978 - Accepted 31 October 1978)

\begin{abstract}
I. An epidemiological study of iron status in general practice has been undertaken. An age-sex register was established and a I0 \% stratified random sample (194 males and 220 females) of the patients above the age of 15 years was studied. A full blood count, serum Fe concentration, transferrin saturation and serum ferritin concentration were measured and correlated with clinical features associated with Fe deficiency.

2. The geometric mean for serum ferritin for males was $77 \mu \mathrm{g} / \mathrm{l}(20-196 \mu \mathrm{g} / \mathrm{l})$ and for females $37 \mu \mathrm{g} / \mathrm{l}$ $(8-177 \mu \mathrm{g} / \mathrm{l}$ ). A low serum ferritin (male $<30 \mu \mathrm{g} / \mathrm{l}$, female $<20 \mu \mathrm{g} / \mathrm{l}$ ) in the absence of anaemia was found in fifteen males and thirty-five females. In this group forty patients had clinical features which are aetiologically associated with $\mathrm{Fe}$ deficiency. The incidence of similar features in a control group of thirty-three patients was seven.

3. It is suggested that this is indirect evidence that serum ferritin concentration is the most sensitive monitor of Fe status enabling the detection of pre-anaemic Fe deficiency.
\end{abstract}

There is an increasing awareness of the importance of marginal iron deficiency as a potential cause of morbidity and impaired health in Western civilization (Jacobs, 1977). Although anaemia is the commonest manifestation of Fe deficiency, it is becoming clear that a wide range of tissue abnormalities occur at different stages of Fe depletion (Dallman, 1974). With the development of the immuno-radiometric assay for serum ferritin it has become recognized that there is a close correlation between serum ferritin concentration and body $\mathrm{Fe}$ stores in normal subjects and in patients with $\mathrm{Fe}$ deficiency and uncomplicated $\mathrm{Fe}$ storage disease (Jacobs et al. 1972; Walters et al. 1973; Lipschitz et al. 1974; Halliday et al. 1977). Cook et al. (1976) have questioned the usefulness of serum ferritin as an epidemiological tool in evaluating the Fe status of a North American population. However they made no attempt to assess the incidence of pre-anaemic Fe depletion.

In the present study an assessment of Fe status in a single general practice in the United Kingdom has been undertaken in an attempt to evaluate the measurement of serum ferritin concentration as a means of detecting pre-anaemic Fe deficiency and its relationship to morbidity.

\section{PATIENTS AND METHODS}

The survey was conducted in an urban general practice of 5500 patients located in South Liverpool. The main surgery was in a predominantly working-class district and a branch surgery $5 \mathrm{~km}$ away was situated in an area of 'owner occupation'. An age-sex register was compiled using the Royal College of General Practitioners' method and 'data' cards (Pinsent, I968). One in ten of the total practice population between 15 and 80 years was sampled using random-number techniques; pregnant and lactating women were included in the survey. Patients were contacted by letter requesting their co-operation and were informed that this would require the taking of a small sample of venous blood.

A total of 4 I4 patients took part in the survey (I94 men and 220 women) and were grouped according to age and sex in the following categories: 1 5-19 years, 20-29 years, 30-39 years, 40-49 years, 50-59 years, 60-69 years and 70-80 years. Of the total number of patients, 315 attended at the first request $(70.5 \%)$. Non-attenders were contacted through relatives, telephone or home visits (to a maximum of three visits). One hundred and three 
house calls were made resulting in a further forty patients recruited to the survey (10\%). Of those participating in the study six $(\mathrm{I} \cdot 4 \%)$ refused to have blood taken. The remaining fifty-three ( $12 \%$ ) non-attenders had either changed address, emigrated or died and a further fifty-three patients were therefore recruited on the same random basis.

At the initial attendance, information on occupation, marital status, family history, smoking habits, alcohol intake and self-medication was recorded on a 'data' sheet. Relevant medical information also recorded included previous illnesses, current illnesses, and present therapy with particular reference to anaemia and to oral contraception. Samples ( $(10 \mathrm{ml})$ of venous blood were collected into sequestrene $(2.5 \mathrm{ml})$ (Searle) and a plain bottle $(7.5 \mathrm{ml})$. A full blood count was estimated on a Coulter Model S counter and the peripheral blood film examined. Serum Fe and transferrin saturation were measured by the method of Young \& Hicks (I965) and serum ferritin concentration was measured immunoradiometrically (Addison et al. 1972). The mean and 'normal' range were assessed for each sex by standard statistical methods (Snedecor \& Cochran, I967).

To assess the relationship of a low serum ferritin concentration to morbidity, males with a serum ferritin concentration $<30 \mu \mathrm{g} / 1$ and females with a level $<20 \mu \mathrm{g} / 1$ were compared with a control group of thirty-three patients selected randomly from the remainder of the subjects sampled. In each case, a comparison was made in terms of the presence or absence of gastrointestinal disease or symptoms, previous gastric surgery, diet, neoplasia, alcoholic intake, tiredness and in females, their obstetrical and gynaecological history. A previous history of anaemia or recent or current $\mathrm{Fe}$ therapy was also noted and clinical details were withheld until the laboratory results had been processed.

\section{RESUL,TS}

The distribution of serum ferritin concentration for 194 males and 195 females, expressed arithmetically, showed an extent of skewness, more marked in the females; the distribution curve was normalized by expressing the serum ferritin concentration logarithmically so that the mean and normal range could be calculated. The mean serum ferritin for males was $77 \mu \mathrm{g} / \mathrm{l}(95 \%$ ) (range 20-296) and for females $37 \mu \mathrm{g} / \mathrm{l}$ (range 8-1 77). These were significantly different. The relationship of serum ferritin concentration to age and sex is shown in Table $I$ together with the incidence of hypoferritinaemia. Females had significantly lower mean serum ferritin concentrations in all groups except in the $70-80$ years age-group. This was most marked up to 49 years of age, after which the mean level for females started to increase towards the mean value for males. In the male population the mean serum ferritin of $46 \mu \mathrm{g} / \mathrm{l}$ in the I $5^{-19}$ years age-group was significantly lower than that of the mean levels in the age-groups beyond 20 years of age.

Fifteen males and thirty-five females had ferritin concentrations less than 30 and $20 \mu \mathrm{g} / \mathrm{l}$ respectively. Four patients had haemoglobin concentrations below $11.5 \mathrm{~g} / \mathrm{dl}$ and nine had mean corpuscular haemoglobin levels below $27 \mathrm{pg}$. In seventeen patients with hypoferritinaemia the transferrin saturation was $16 \%$ or less, compared with twenty-four patients in the survey as a whole. A comparison of the incidence of clinical features is shown in Table 2. Seventeen patients (seven males and ten females) with low serum ferritin concentrations had evidence of gastrointestinal disease ranging from previous gastrointestinal surgery for peptic ulceration or neoplasia in three cases, to dyspepsia in the presence of a normal barium meal. In comparison, the control group contained six patients (three male and three female) who had mild occasional dyspepsia. The diet of thirteen patients in the low ferritin group was inadequate; two of these were mentally subnormal and living in an institution, and one, a woman, had been on a strict reducing diet for 12 months which had resulted in reducing her weight by $12 \mathrm{~kg}$. 
Table 1. Serum ferritin concentration in relation to age and sex in adult subjects between $\mathrm{I} 5$ and 80 years of age

(The 'normal' range (i.e. $95 \%$ range) for males is $20-296 \mu \mathrm{g} / \mathrm{l}$ and for females is $8-177 \mu \mathrm{g} / \mathrm{l}$ )

\begin{tabular}{|c|c|c|c|c|c|c|c|c|c|c|}
\hline \multirow[b]{3}{*}{$\begin{array}{l}\text { Age range } \\
\text { (years) }\end{array}$} & \multicolumn{5}{|c|}{ 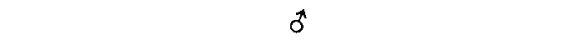 } & \\
\hline & \multirow[b]{2}{*}{$\begin{array}{c}\text { Geometric } \\
\text { mean }\end{array}$} & \multirow[b]{2}{*}{$\begin{array}{l}\text { Observed } \\
\text { range }\end{array}$} & \multirow[b]{2}{*}{ Total } & \multicolumn{2}{|c|}{$<30 \mu \mathrm{g} / 1$} & \multirow[b]{2}{*}{$\begin{array}{c}\text { Geometric } \\
\text { mean }\end{array}$} & \multirow[b]{2}{*}{$\begin{array}{l}\text { Mean } \\
\text { range }\end{array}$} & \multirow[b]{2}{*}{ Total } & \multicolumn{2}{|c|}{$<20 \mu \mathrm{g} / 1$} \\
\hline & & & & $\overparen{\text { No }}$ & $\%$ & & & & No & $\%$ \\
\hline $15-19$ & $46 \cdot 2$ & $8-170$ & 13 & 1 & 8.0 & 26 & $10-73$ & 14 & 4 & 29.0 \\
\hline $20-29$ & $84^{\circ} 0$ & $18-283$ & 32 & 4 & 12.5 & 43 & $2-130$ & 34 & 4 & 12.0 \\
\hline $30-39$ & 102.0 & $37-220$ & 26 & 0 & 0 & 28 & $4-98$ & 27 & 7 & $26 \cdot 0$ \\
\hline $40-49$ & $57^{\circ} 0$ & 9-294 & 28 & 3 & $11 \cdot 0$ & 32 & $9-126$ & 29 & 8 & 28.0 \\
\hline $50-59$ & $92 \cdot 0$ & $22-294$ & 33 & 3 & 9.0 & 39 & $9-150$ & 34 & 5 & 15.0 \\
\hline $60-69$ & 73.0 & $8-242$ & $3 I$ & 4 & 13.0 & $4 I$ & $4-154$ & 32 & 4 & 12.5 \\
\hline $70-80$ & $78 \cdot 0$ & $41-153$ & I4 & 0 & 0 & 48 & $7-172$ & 25 & 3 & $12 \cdot 0$ \\
\hline All groups & $77^{\circ} 0$ & $8-297$ & 177 & 15 & $8 \cdot 5$ & 37 & $2-172$ & I95 & 35 & $18 \cdot 0$ \\
\hline
\end{tabular}

Table 2. A comparison of the incidence of clinical features in adult subjects between 15 and 80 years of age with low serum ferritin $<30 \mu \mathrm{g} / \mathrm{l}$ and a control group

\begin{tabular}{|c|c|c|c|c|c|c|}
\hline & \multicolumn{3}{|c|}{ Low-ferritin group } & \multicolumn{3}{|c|}{ Controls } \\
\hline & $\hat{0}$ & q & Total & $\delta$ & 우 & Total \\
\hline Gastrointestinal disease & 7 & IO & 17 & 3 & 3 & 6 \\
\hline Gastric survey & 2 & $\mathbf{I}$ & 3 & 0 & 0 & 0 \\
\hline Inadequate diet & 4 & 9 & 13 & 0 & 0 & 0 \\
\hline Obstetric or gynaecological history & - & II & II & - & I & $\mathbf{I}$ \\
\hline Neoplasia & 2 & I & 3 & I & 0 & I \\
\hline Excessive alcohol intake & 2 & $\mathbf{I}$ & 1 & 0 & 0 & 0 \\
\hline Tiredness* & I & 6 & 7 & 0 & 0 & o \\
\hline Absence of these features & 2 & 6 & 8 & 9 & 16 & 25 \\
\hline
\end{tabular}

* Tiredness occurred in two patients in the absence of a cause of iron deficiency.

A significant obstetric or gynaecological history in terms of heavy menstrual bleeding, multiparity or recurrent abortions was seen in eleven women in the low-ferritin group. There was one woman in the third trimester of pregnancy who had failed to take Fe supplementation regularly. Tiredness was a feature in seven patients in the low-ferritin group, as was a history of excessive alcohol intake in three others, although neither feature occurred in the control group. Eight of the fifty subjects in the low-ferritin group and twenty-five of the thirty-three in the control group had none of the clinical features listed.

\section{DISCUSSION}

The concentration of serum ferritin correlates closely with body Fe stores in normal subjects and in patients with $\mathrm{Fe}$ deficiency and uncomplicated $\mathrm{Fe}$ overload disease. In evaluating the Fe status in a selected American population Cook et al. (1976) used the serum ferritin concentration, transferrin saturation and red cell protoporphyrin levels and found that a single abnormal factor was associated with a prevalence of anaemia of $10.9 \%$ as compared with a prevalence of $8.3 \%$ in the population as a whole. The occurrence of two abnormal factors increased the incidence to $28 \%$ and when all three factors were abnormal the incidence increased to $63 \%$. Similarly, Derman et al. (1978) surveying the nutritional status of rural and urban South African children found that the prevalence of anaemia in those 
children with ferritin levels $<\mathrm{I} 2 \mu \mathrm{g} / 1$ was only slightly higher than in the group as a whole, 38.8 v. $24.3 \%$. However, the combination of a serum ferritin of $12 \mu \mathrm{g} / \mathrm{l}$ and a transferrin saturation $<16 \%$ increased the incidence of anaemia to $70 \%$. In both these studies the various measurements of Fe status were assessed by their ability to detect anaemia, which is a late development of Fe deficiency. Furthermore, both the reduction of the transferrin saturation below $16 \%$ and the increase in erythrocyte protoporphyrins are similarly late findings in progressive Fe deficiency, and would not be expected in the pre-anaemic patient.

In this present study serum ferritin concentration has been correlated with clinical features to evaluate its ability to detect pre-anaemic Fe deficiency. Unlike Cook's (Cook et al. 1976) study, sampling was completely random and pregnant and lactating women were included. The mean serum ferritin of the men was $77 \mu \mathrm{g} / 1$ and was significantly higher than that of the women which was $37 \mu \mathrm{g} / 1$. This sex difference existed at all ages even in the 60-69 and 70-79 year age-groups when the mean level among women might be expected to approximate that among men. These results are in keeping with previous findings and can be accounted for by the extra demand for Fe due to menstruation and childbirth but suggest that the Fe stores are not always repleted after the menopause. In the 15-29 years age-group both the men and women had mean levels significantly lower than in other age-groups of their sex and again this appears to reflect the demand for $\mathrm{Fe}$ during a period of high growth activity. The serum ferritin concentration remained constant from 20 years of age onwards in the men but in the women there was a tendency for it to decrease from a mean value of $43 \mu \mathrm{g} / 1$ for the 30-39 years age-group, throughout the child-bearing years with a subsequent increase from 50 years of age onwards. This latter trend was not as marked as had been noted previously (Cook et al. 1976).

The incidence of hypoferritinaemia was not related to age in men but increased with age in women until after the age of 59 years when it began to decrease again, reflecting the demands for $\mathrm{Fe}$ of menstruation and pregnancy.

All but ten patients (two males and eight females) in the low ferritin group had clinical features which are frequently associated with Fe deficiency. By comparison twenty-five of the thirty-three patients in the control group were asymptomatic; six having mild intermittent dyspepsia and one woman heavy periods. The low occurrence of anaemia in the hypoferritinaemic group reflects the incidence of pre-anaemic Fe deficiency in the population. Since anaemia is a late manifestation of Fe depletion, it would be expected that there would be a group of non-anaemic hypoferritinaemic patients who have clinical features associated with Fe depletion.

This present study confirms this expectation and provides indirect evidence that the measurement of serum ferritin is a sensitive factor for evaluating Fe status epidemiologically. Furthermore, it suggests that $8.9 \%$ of men and $18.0 \%$ of women have pre-anaemic Fe deficiency and might therefore benefit from Fe supplementation.

This study was supported by the Mersey Regional Health Authority and Abbott Laboratories Limited, Queenborough, Kent, MEI I 5 EL. The authors would like to express thanks to them and also to Mrs J. Leighton for her assistance in setting up the age-sex register; to $\mathrm{Mr}$ C. West of the Biostatistic Unit of the Faculty of Medicine, University of Liverpool, for help in the statistical analysis and to Miss S. Warburton for typing the copy.

\section{REFERENCES}

Addison, G. M., Beamish, M. R., Hales, C. N., Hodgkins, M., Jacobs, A. \& Llewellin, P. (1972). J. clin. Path. $25,326$.

Cook, J. D., Finch, C. A. \& Smith, N. J. (1976). Blood 48, 449.

Dallman, P. (1974). In Iron in Biochemistry and Medicine, p. 437 [A. Jacobs and M. Worwood, editors]. London: Academic Press. 
Derman, D. P., Lynch, S. R., Bothwell, T. H., Charlton, R. W., Torrance, J. D., Brink, B. A., Margo, G. M. \& Metz, J. (1978). Br. J. Nutr. 39, 383.

Halliday, J. W., Russo, A. M., Cowlishaw, J. L. \& Powell, L. W. (1977). Lancet ii, 621.

Jacobs, A. (1977). Clin. Sci. 53, 105.

Jacobs, A., Miller, F., Worwood, M., Beamish, M. R. \& Wardrop, C. A. (1972). Br. med. J. iv, 206.

Lipschitz, D. A., Cook, J. D. \& Finch, C. A. (1974). New Engl. J. Med. 290, I213.

Pinsent, R. J. F. H. (1968). J. R. Coll. Gen. Practit. 16, I 27.

Snedecor, G. W. \& Cochran, W. G. (1967). Statistical Methods. Iowa: Iowa State University Press.

Walters, G. O., Miller, F. M. \& Worwood, M. (1973). J. clin. Path. 26, 770.

Young, D. G. \& Hicks, J. M. (1965). J. clin. Path. 18, 98. 